\title{
Safeguards to Prevent Neurologic Complications after Epidural Steroid Injections: Analysis of Evidence and Lack of Applicability of Controversial Policies
}

\author{
Laxmaiah Manchikanti, MD¹, and Frank J.E. Falco, MD²
}

From: 'Pain Management Center of Paducah, Paducah, $\mathrm{KY}$, and University of Louisville, Louisville, KY; and ${ }^{2}$ Mid Atlantic Spine \& Pain Physicians, Newark, $\mathrm{DE}$, and Temple University Hospital, Philadelphia, PA.

Dr. Manchikanti is Medical Director of the Pain Management Center of Paducah,

Paducah, KY, and Clinical

Professor, Anesthesiology and Perioperative Medicine,

University of Louisville,

Louisville, KY. Dr. Falco is

Medical Director of Mid Atlantic

Spine \& Pain Physicians, Newark,

DE; Director, Pain Medicine

Fellowship Program, Temple

University Hospital, Philadelphia,

PA; and Adjunct Associate

Professor, Department of PM\&R,

Temple University Medical

School, Philadelphia, PA.

Address Correspondence: Laxmaiah Manchikanti, M.D. 2831 Lone Oak Road Paducah, KY 42003

E-mail:drlm@thepainmd.com

Disclaimer: There was no external funding in the

preparation of this manuscript. Conflict of interest: Dr.

Manchikanti has provided

limited consulting services

to Semnur Pharmaceuticals, Incorporated, which is

developing nonparticulate steroids. Dr. Falco is a consultant

for St. Jude Medical Inc. and Joimax Inc.

Manuscript received: 03-08-2015

Accepted for publication: 03-11-2015

Free full manuscript: www.painphysicianjournal.com

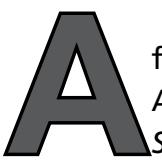

fter extensive debate and investigation by the Food and Drug Administration (FDA), Rathmell et al (1) published the final document of Safeguards to Prevent Neurologic Complications after Epidural Steroid Injections. This is a product of consensus by 13 national organizations known as the Multisociety Pain Workgroup (MPW), excluding the American Society of Intervention Pain Physicians (ASIPP), an organization with mission and objectives to promote the development and practice of safe, high quality, cost-effective interventional pain management techniques. This article follows the warning issued by the FDA on April 23, 2014 that the injection of corticosteroids into the epidural space of the spine may result in rare, but serious adverse events, including "loss of vision, stroke, paralysis, and death" (2). This warning was issued without consensus or consultation of the safe use initiative (SUI) established by the FDA (3). Following this, significant controversy with multiple manuscripts and a citizen petition opposing the warning along with communication to the FDA, members of Congress, and, finally, a letter signed by 1,040 interventional pain physicians to withdraw the FDA warning and a request not to implement regulations emerged (3-7). The final version of Rathmell et al's (1) article which appeared in press is slightly different than the MPW's press release (8). The final version published and considered by MPW failed to meet consensus of FDA SUI (9). In fact, these were considered by MPW which ceased to develop LCDs.

\section{Publication of Safeguards from the MPW}

Rathmell et al (1) described this work as a collaboration undertaken by the U.S. FDA SUI, an expert multidisciplinary working group, and 13 specialty stakeholder societies. The goal of this collaboration was to review the existing evidence regarding neurologic complications associated with epidural corticosteroid injections and produce consensus procedural clinical considerations aimed at enhancing the safety of these injections. Consequently, 17 clinical considerations aimed at improving safety were produced by the stakeholder societies. Safeguards include specific clinical considerations for performing transforaminal and interlaminar injections including the use of nonparticulate steroids, anatomic considerations, and use of radiographic guidance. The manuscript (1) states that they have provided the existing scientific evidence for each clinical consideration.

This manuscript (1) described well the background information including anatomic laboratory and animal studies, possible mechanisms of injury, and the role of the FDA SUI. However, the methodology and results suffer with inaccuracies 
and a lack of evidence. This manuscript (1) states that the SUI convened and facilitated teleconferences conducted by the working group, which drafted, discussed, and formulated a set of clinical consideration designed to minimize the risk of complications, and clinical considerations were formulated with reference to the best available scientific evidence or expert opinion from leading scientific societies or associations or experts in the subject of epidural injections. The manuscript also states that once clinical considerations were drafted, representatives from a number of national pain organizations were invited to review and vote on them.

\section{The Role of FDA Safe Use Initiative}

However, from our personal experience with participation in SUI (Laxmaiah Manchikanti, MD. and Frank Falco, MD) and based on the publication from the FDA (3), this information may not be quite accurate. In short, the FDA created the SUI in 2009 to create and facilitate public and private collaborations within the health care community. The SUI facilitated the organization of an expert working group of key stakeholders created to understand the causes of neurologic injuries associated with epidural steroid injections and devise strategies to mitigate the risk. This was initiated by Rathmell and the working group included Drs. Benzon, Aprill, Bogduk, Dreyfuss, Huntoon, Riew, Rosenquist, Rost, and Wallace (3). The working group drafted, discussed, and formulated a set of 20 clinical considerations to minimize the risk of catastrophic neurological injury associated with epidural steroid injections. Subsequent to this, the FDA invited other organizations to participate in the SUI in 2012. The organizations participating in SUI were different from the MPW. Participants in SUI included Weistroffer from American Academy of Orthopedic Surgeons (AAOS); Lamer from American Academy of Pain Medicine (AAPM); Sullivan from American Academy of Physical Medicine and Rehabilitation (AAPM\&R);; Miguel from American Society of Anesthesiologists (ASA); Falco from American Society of Interventional Pain Physicians (ASIPP); Buvanendran from American Society of Regional Anesthesia (ASRA); Dreyfuss and Duszynski from Interventional Spinal Intervention Society (ISIS); and Rathmell from Massachusetts General Hospital; Kreiner, Hayden, and Rosolowski from North American Spine Society (NASS); Benzon from Northwestern University/Feinberg School of Medicine; Enterline and Prince from Society of Interventional Radiology (SIR); Huntoon from Vanderbilt Department of Anesthesiology; and Wallace from University of Califor- nia San Diego (UCSD) (9). There were multiple meetings of SUI and the final one was held on January 31, 2013. There were significant disagreements on portions of each safeguard developed by the working group of the SUI. Subsequently, comments were sent, and after the appropriate responses at the end of 2013, it was clear that there was no consensus among the SUI. Importantly, the SUI consisted of 8 of the 13 societies on the MPW. ASIPP was part of the MPW, but exited on May 27, 2013, due to the unscientific collation and controversial consensus basis with a Google doc process to approve or disapprove the statements. This decision was made by ASIPP's Executive Committee to facilitate discussions, as organizations participating in federal guidance shall not oppose or request modifications. The consideration of safeguards by MPW was long after the exit of ASIPP and also after the activities of the MPW were suspended by Noridian. However, ASIPP continues to be part of the SUI and expressed its disappointment at the decision to hand over the epidural

\section{Assessment of Evidence to the MPW}

Rathmell et al (1) stated that recommendations are based on the available best scientific evidence, and when evidence was lacking, expert opinion was sought both within the working group and from leading scientific societies or associations with interest or expertise in the subject of epidural injections. ASIPP has provided abundant literature; however, none of this appeared to have been considered in theirrecommendations.

Rathmell et al's (1) recommendations for cervical and lumbar interlaminar epidural injections are to use fluoroscopy with appropriate lateral or oblique views in addition to anteroposterior views to gauge the depth of needle insertion to avoid penetration of the spinal cord. They provide 2 manuscripts by Landers et al (10) describing geometry of fluoroscopic views for cervical interlaminar epidural injections and Furman et al (11) describing a technical note of fluoroscopic contralateral oblique view in interlaminar interventions. Further, they state that relying on loss of resistance or on anteroposterior views alone does not predict accurate needle placement and avoid the risk of spinal cord injection with either air, saline, contrast medium, or other solutions. Landers et al (10) published their manuscript with review of illustrations, cadaver models, and deriving a mathematical model to demonstrate the utility of the contralateral oblique fluoroscopic view during the performance of cervical interlaminar epidural injections. The technical note by Furman et al (11) also 
describes the value of the contralateral oblique view in performing cervical, thoracic, and lumbar interlaminar procedures. However, neither of the references defined the need for the oblique or lateral view in each and every case, instead they described the contralateral oblique view. The authors (1) have not considered significant literature and discussions of the contralateral oblique view which was the subject of Furman et al's manuscript (11-18). More importantly, the authors (1?) have not discussed or even mentioned the difficulties of assessing the depth of the cervical epidural space based on cervical anatomy and body surface area (19). Fujinaka et al (19) showed that accurate depth was measured within plus or minus $0.5 \mathrm{~cm}$ of actual depth in only $69 \%$ of the patients, whereas in others, the prediction was inaccurate by as much as $1.6 \mathrm{~cm}$ or $1.7 \mathrm{~cm}$.

Overall, it is essential to determine the necessity of the lateral or oblique view prior to mandating it universally for these procedures. In an overwhelming majority of the cases with careful advancement of the needle under fluoroscopy in the posteroanterior view with loss of resistance technique in conjunction with contrast injection, illustrating appropriate positioning with spread into the epidural space and even nerve roots confirming the appropriate position, the need for the lateral or oblique view is eliminated. These mandated views can be associated with difficult positioning, increased radiation exposure, increased time, and potential for increased dural puncture. Further, many physicians have not been trained in these techniques and are unaware of them. The literature and discussions mandating the use of a lateral or oblique view in lumbar epidurals are even less convincing (16-24).

Rathmell et al (1) essentially mandate needle entry for cervical interlaminar epidural injections at C7$\mathrm{T} 1$, with a caveat of not higher than the $\mathrm{C6}-\mathrm{C} 7$ level. This guidance does not take into consideration the fact that the ultimate choice of what approach or technique to use should be made by the treating physician after balancing potential risks versus benefits, as described in Rathmell et al (1). To support this assertion of C7-T1 entry, they provide literature on the narrow epidural space, making the dural sac and spinal cord more susceptible to penetration and injury above C7-T1 (25-28). They (1) also provided a recommendation on inspection of adequate epidural space at the segmental level to admit a needle safely. Ironically, one of the manuscripts the authors quoted (29) showed that magnetic resonance imaging (MRI) did not improve treatment outcomes in patients with a wide range of spinal disorders.
Thus, this indirectly mandates, without any evidence, that the treating physician and review the MRI without crediting a radiologist's opinion in each and every case. Further, Hodges et al (25) described epidural steroid injection with intrinsic spinal cord damage in 2 patients with dural puncture at $\mathrm{C5}-\mathrm{C} 6$. This was due to heavy intravenous sedation, which resulted in a diminution (30) of the patient's ability to experience the expected pain and paresthesias at the time of spinal cord irritation. Further, they injected bupivacaine, fentanyl, and particulate steroid. The authors (25) concluded that the patient should be fully awake during the administration of cervical epidural steroid injection. Rathmell et al (1) also used Aldrete et al's (26) manuscript describing skin to cervical epidural space distances as read from MRI films, essentially stating that such estimations may not be reliable. This, however, does not support the assumption that procedures should be performed at C7-T1. Hogan (27) showed the lack of posterior epidural space above the C7-T1 level, implicating the potential for $100 \%$ dural puncture at $\mathrm{C} 6-\mathrm{C} 7$ and above. This study included 26 adult bodies frozen in total with examination of cryomicrotome sections. Finally, manuscript by Goel and Pollan (28) described contrast flow characteristics in the cervical epidural space with an analysis of cervical epidurograms. Goel and Pollan (28) hypothesized that lower levels, C6-C7 and C7-T1, were thought to be safer due to the large epidural space, as compared with higher levels. In fact, Lirk et al (31), in a publication after Hogan et al's publication (27), with cryomicrotome sections, showed that cervical and high thoracic ligamentum flavum variably fails to fuse in the midline. The described gaps in the ligamentum flavum were $11 \%$ at $\mathrm{T} 2-\mathrm{T} 3,21 \%$ at $\mathrm{T} 1-\mathrm{T} 2,51 \%$ at $\mathrm{C} 7-\mathrm{T} 1,64 \%$ at $\mathrm{C} 6-\mathrm{C} 7,74 \%$ at $\mathrm{C} 5-\mathrm{C} 6,58 \%$ at $\mathrm{C} 4-\mathrm{C} 5$, and $66 \%$ at $\mathrm{C} 3-$ C4 (31). Essentially this study showed that there is substantial risk at C7-T1 also. The risk increases from $21 \%$ of gaps at T1-T2 to $51 \%$ at C7-T1 (31). Ironically at C4C5 there seems to be less incidence of absent midline gaps with $58 \%$ compared to $74 \%$ at C5-C6. Additionally, significant variations have been described in cervical neural canal diameters $(32,33)$. In fact, this variation in cervical canal dimension has precluded the definition of spinal stenosis, even though it may be important in administration of interlaminar epidural injections. Based on these studies, cervical anterior-posterior diameter was narrowest at the C4 level for AfricanAmericans and $\mathrm{C} 6$ for Caucasians, ranging from 13.16 $\mathrm{mm}$ to $21.9 \mathrm{~mm}$. Cervical transverse ligaments ranged from $18.89 \mathrm{~mm}$ to $24.02 \mathrm{~mm}$. In addition, the studies 
also have shown that the actual size of the posterior epidural space is greatest with $5 \mathrm{~mm}$ to $6 \mathrm{~mm}$ in the mid lumbar spine and gradually decreases to $3-5 \mathrm{~mm}$ in the mid thoracic region, $3-4 \mathrm{~mm}$ at $\mathrm{T} 2$, and $1.5-2$ $\mathrm{mm}$ at $\mathrm{C} 7$ (33).

Thus, the available data affirms that the restriction at C7-T1 is not based on evidence, and may increase the risk, specifically with multiple maneuvers of the fluoroscopic unit, to not only the physician, but also to the patient and personnel. Further, none of the studies have shown the prevalence of incidence of subarachnoid placement of the needle anywhere near to the incidence of midline gaps. Manchikanti et al (34), in an assessment of 2,376 fluoroscopically directed cervical interlaminar epidurals, reported dural puncture in $1 \%$ or 24 patients. In addition, a recent manuscript (35), describing 4,398 cervical interlaminar epidurals performed with 1,228 at C7-T1, 1,835 at C6-C7, and 1,335 at C5-C6, showed subarachnoid placement of the needle in $1.4 \%$ total with $1.7 \%$ at $\mathrm{C} 7-\mathrm{T} 1,0.87 \%$ at $\mathrm{C} 6-\mathrm{C} 7$, and $1.79 \%$ at C5-C6. Many experienced interventionalists, performing a large number of these procedures, have utilized C6-C7 and $\mathrm{C} 5-\mathrm{C} 6$ as a preferred level based on the anatomy, contrast flow patterns, and location of the pathology and reported minimal or similar complications as when it is performed at C7-T1 or C6-C7. Ironically, the recent manuscript (35) showed a lesser incidence of subarachnoid placement when performed at $\mathrm{C} 6-\mathrm{C} 7$ with $0.87 \%$ (statistically insignificant) compared to $1.7 \%$ and $1.79 \%$ at C7-T1 and C5-C6. There was no difference between C5-C6 and C7-T1 level; further, performance at C5-C6 facilitates an easier lateral view without embarking on numerous alternate techniques and with minimal scatter radiation exposure. In a series of recent manuscripts in Anesthesia \& Analgesia, it was clearly shown that patients managed by low performance anesthesiologists (corresponding to the twenty-fifth percentile of the distribution of anesthesiologist risk adjusted outcomes) experienced almost twice the rate of death or serious complications (36-41).

Authors (1) describe appropriately the causes of complications with cervical interlaminar as being related to the sedation and intraarterial injection with cervical and lumbar transforaminal epidural injections. They recommended dexamethasone for transforaminal epidural injections and to avoid particulate steroids; however, there are no safety studies of cervical and lumbar transforaminal injections in relation to particulate steroids or nonparticulate steroids. The recommen- dation to use dexamethasone does not take into consideration the four deaths reported to the FDA from injections done using dexamethasone. Further, the FDA describes no significant benefit with nonparticulate steroids in relation to complications. Based on the comments of the manuscript (1), the studies utilized to support the efficacy of nonparticulate steroids $(42,43)$ appear to have been considered after the conclusions were drawn. Among these, Kennedy et al (43) assessed 78 consecutive patients with acute unilevel disc herniation with unilateral radicular pain. The follow-up was short-term and there was a relatively small number of patients for a multicenter trial. They showed surgical rates of $14.6 \%$ in the dexamethasone group and $18.9 \%$ of triamcinolone group. Based on this small study with short-term follow-up, they concluded that dexamethasone appears to possess reasonably similar effectiveness when compared with triamcinolone. The second manuscript, by El-Yahchouchi et al (42), was a retrospective noninferiority analysis of dexamethasone relative to particulate steroids which included 3,645 lumbar transforaminal epidural injections performed on 2.634 patients; however, the follow-up was only at 2 weeks and 2 months. They concluded that dexamethasone was noninferior to the particulate steroids in pain relief and functional improvement at 2 months. However, the efficacy of local anesthetic has been shown to be similar to particulate steroids in all spinal conditions except disc herniation (44-58). Rathmell et al (1) have omitted multiple other manuscripts, not only the ones comparing various types of steroids, but also those comparing local anesthetics with steroids, which basically showed the equal effectiveness of local anesthetics except in disc herniation during initial period of treatment (44-58). Further, Park et al (59) showed the superiority of triamcinolone compared to dexamethasone in a randomized, controlled trial with 53 patients in each group; however, again with a short-term follow-up. In addition, they also have not included the manuscript by 3 of the authors of the safeguards which showed a greater effect of triamcinolone in a short-term followup in a small sample size (60).

Majority of the authors endorsed digital subtraction angiography (DSA) for transforaminal injections on the grounds that it significantly increases the detection of vascular uptake of contrast medium (61-63). They (2) also claim that it requires less contrast medium to detect vessels; however, it requires significant investment, increased time, and substantially increased radia- 
tion (64). They (1) have quoted the sensitivity of DSI to be only $60 \%$ compared with $20 \%$ with aspiration (63). Instead, others have emphasized the disadvantages of DSAand its lack of accuracy (65-67). A recent systematic review (66) has concluded that DSA had a $32 \%$ improvement (OR $=1.32$ ) for detection of intravascular penetration with epidural steroid injection when compared to real time fluoroscopy. Thus, there is a greater than $30 \%$ "missed-events" rate for detection of vascular penetration when using real time fluoroscopy, which does not correlate with the generally reported cumulative rate of complications (1\%). The authors concluded that this discrepancy suggests that factors other than vascular events also play a role in complications. Candido (67), in a commentary, elaborated numerous issues with the accuracy and disadvantages of DSA.

Other safeguards such as extension tubing has not been based on any scientific basis. More importantly, the authors (1) appear to have not considered the placement of the needle at the inferior aspect of the intervertebral foramina instead of the superior foramina (supraneural approach or safe triangle approach) as advocated by International Spine Intervention Society (ISIS) $(68,69)$, while at the same time they have nominally considered other approaches (70-72). In considering these approaches, they utilized a manuscript by Windsor et al (72) describing cervical transforaminal injections; however, alternate approaches for cervical epidural injections may be irrelevant considering that radicular arteries are present in all quadrants anterior, ventral, and posterior dorsal (73-82). They quote the references by Park et al (83) showing the equivalent results of the Kambin triangle versus the supraneural approach for the treatment of lumbar radicular pain. In addition, in a comprehensive review (70), Atluri et al (70) analyzing the needle position data of paralysis from transforaminal epidurals showed that in all patients complications resulted after performing the procedures with a safe triangle approach. Further, based on Atluri et al's (70) review there is overwhelming literature illustrating that the distribution of radicular arteries can be avoided with almost certainty with alternate approaches in lumbar transforaminal epidural injections. Even then, caution must be exercised considering multiple risk factors in each and every patient. They considered this as an untested safeguard similar to a specific needle tip type. It appears that these alternate approaches and type of needle tips have even more evidence than many of the other safeguards as- similated. However, Rathmell et al (1) do not discuss the role of blunt needles in systematically changing the technique by which transoforaminal injections are done, thus removing the risk of intraarterial injection. Further, there were no discussions in reference to caudal epidural injections which are performed with the same frequency as interlaminar epidural injections.

Apart from neurological complications of intraarterial injections, arachnoiditis has been a major issue. We believe that arachnoiditis is secondary to not only particulate steroids with preservatives, but with repeated injections of steroids into the compromised epidural space after surgery with scar tissue, inadvertently entering the subarachnoid space $(3,4,8,84,85)$. In addition, lack of identification of epidural space is aided by injection of high dose steroids and saline without local anesthetic to facilitate subarachnoid entry and injection $(3,4,8,84,85)$. In fact, the Department of Phamacovigilance II (DPV) identified 131 FDA Adverse Event Reporting System (FAERS) cases of neurologic fatalities, which also included 41 cases of arachnoiditis (3). In addition, the outbreak of fungal meningitis included 751 cases with 64 deaths due to contaminated methylprednisolone acetate (86).

The greatest risk of neurologic comprise arises from cervical transforaminal injections. Safety considerations for cervical transforaminal epidural injections have been extended to all procedures. The statistics show that transforaminal epidurals injections have increased substantially in the cervical/thoracic regions and lumbosacral regions. There was an astonishing $577 \%$ increase per 100,000 fee-for-service Medicare recipients with an annual increase of $16 \%$ from 2000 to 2013 for lumbosacral transforaminal epidural injections $(87,88)$. In contrast, for cervical and thoracic transforaminal epidural injections, the increase has been $84 \%$ with an annual increase of $5 \%$, and for caudal and lumbar interlaminar epidural injections, the increase has been $11 \%$ with an annual increase of $1 \%$. Cervical and thoracic interlaminar epidural injections have increased $119 \%$ with an annual increase of $6 \%(87,88)$. As authors of safeguards (1) accurately described that the injection of particulate steroids in transforaminal epidural injections is associated with devastating complications with infarctions of the spinal cord, brain stem, cerebrum, or cerebellum $(1,4,8,73,80-82)$. However, it is not justifiable to transfer these complications to all epidural injections. The authors also quote the survey by Scanlon et al (82) who surveyed 1,340 physicians with 
an overall response rate of $21.4 \%$ (287 of 1340). In all, 78 complications were reported, including 16 vertebrobasilar brain infarcts, 12 cervical spinal cord infarcts, and 2 combined brain/spinal cord infarcts. They (82) concluded that their study demonstrated a significant risk of serious neurologic injury after cervical transforaminal epidural steroid injections. Engel et al (73) in a subsequent publication reported similar results of serious complications, including 13 deaths and many catastrophic neurological injuries.

A growing body of evidence supports an embolic mechanism, whereby inadvertent intra-arterial injection of particulate corticosteroid causes a distal infarct. Embolism to the distal basilar artery region can cause midbrain, pons, cerebellum, thalamus, temporal, and occipital lobe infarctions. Other potential mechanisms of infarction include needle-induced vasospasm and vertebral artery perforation causing dissection/thrombosis and needle-induced vasospasm $(73,80,82)$. In reference to the mechanisms, Rathmell et al (1) state that circumstantial evidence and some direct evidence implicates a variety of possible mechanisms for these complications. They describe injection into the radicular medullary artery as the major culprit (81). They also described the mechanism of particulate formation; however, none of the studies thus far have assessed the mechanism and pathoetiology of particle formation when combined with plasma or blood products $(80,89,90)$. This is an area being investigated. Even though the authors state that injection of particulate steroids in experimental settings (91) did not show significant damage after injection of dexamethasone, the FDA has described that the damage is caused by both particulate and nonparticulate steroids (3). Rathmell et al (1) have minimized other potential mechanisms of injury, including perforation (92) and traumatic aneurysm caused by penetration with the needle (93), arterial spasm, and creation of an intimal flap, coming to the conclusion that there is a lack of direct evidence for these alternate mechanisms of neurologic injury (89). Despite these assertions, literature supports these alter- nate theories $(74,75,94,95)$.

\section{Preventive Strategies}

Thus, overall the manuscript (1) reflects a lack of appropriate assessment of evidence, despite a high profile project started in 2009, with substantial resource allocation and anguish among interventional pain management community, the manuscript is based on conjuncture, creating confusion about the recommendation of safeguards. We suggest the following 5 simple measures to prevent neurological complications of not only intraarterial injections, but also arachnoiditis :

1. Establish appropriate medical necessity and indications with appropriate route and drugs of administration.

2. Understand prevalence of complications, pathoanatomy, and mechanism of injury.

3. Mandate fluoroscopy for all procedures, however, without mandating multiple views. Do not inject through scar tissue after surgery with or without steroids and with or without fluoroscopy.

4. Utilize alternate approaches to lumbar transforaminal epidural injections considering the multiple risk factors in each patient with evidence showing that local anesthetic may be as effective as either particulate or nonparticulate steroids $(44,45,54,70,74,75,83,84,93-97)$.

5. Do not perform cervical transforaminal epidural injections with or without steroids due to the lack of accuracy and efficacy until either their accuracy for diagnostic purposes or efficacy for therapeutic purposes is proven in high quality diagnostic or randomized controlled trials $(73,80-82,84,96-116)$.

\section{Acknowledgments}

The authors wish to thank Laurie Swick, BS for manuscript review, and Tonie M. Hatton and Diane E. Neihoff, transcriptionists, for their assistance in preparation of this manuscript. We would like to thank the editorial board of Pain Physician for review and criticism in improving the manuscript. 


\section{References}

1. Rathmell JP, Benzon HT, Dreyfuss P, Huntoon M, Wallace M, Baker R, Riew $K D$, Rosenquist RW, Aprill C, Rost NS, Buvanendran A, Kreiner DS, Bogduk N, Fourney DR, Fraifeld E, Horn S, Stone J, Vorenkamp K, Lawler G, Summers J, Kloth D, O'Brien D Jr, Tutton S. Safeguards to prevent neurologic complications after epidural steroid injections: Consensus opinions from a multidisciplinary working group and national organizations. Anesthesiology 2015 Feb 9. [Epub ahead of print].

2. U.S. Food and Drug Administration. Drug Safety Communications. FDA Drug Safety Communication: FDA requires label changes to warn of rare but serious neurologic problems after epidural corticosteroid injections for pain.

www.fda.gov/downloads/Drugs/DrugSafety/UCM394286.pdf

3. Food and Drug Administration. Anesthetic and Analgesic Drug Products Advisory Committee Meeting. November 24-25, 2014. Epidural steroid injections $(E S I)$ and the risk of serious neurologic adverse reactions. www.fda.gov/downloads/AdvisoryCommittees/CommitteesMeetingMaterials/Drugs/AnestheticAndAnalgesicDrugProductsAdvisoryCommittee/UCM422692.pdf

4. Manchikanti L, Candido KD, Singh V, Gharibo CG, Boswell MV, Benyamin RM, Falco FJE, Grider JS, Diwan S, Staats PS, Hirsch JA. Epidural steroid warning controversy still dogging FDA. Pain Physician 2014; 17:E451-E474.

5. Candido KD, Knezevic NN, Chang-Chien GC, Deer TR. The Food and Drug Administration's recent action on April 23, 2014, failed to appropriately address safety concerns about epidural steroid use. Pain Physician 2014; 17: $\mathrm{E}_{549}-\mathrm{E}_{552}$.

6. Letter to Margaret Hamburg, MD, Commissioner, and Salma Lemtouni, MD, MPH, Office of the Center Director, Center for Drug Evaluation and Research, U.S. Food and Drug Administration (FDA), RE: FDA Safe Use Initiative of Epidural Steroids Evaluation with Assignment of Responsibility to Multisociety Pain Workgroup (MPW) from American Society of Interventional Pain Physicians (ASIPP) and 1,040 interventional pain physicians, June 26, 2014.

7. Manchikanti L, Falco FJE, Benyamin RM, Gharibo CG, Candido KD, Hirsch JA. Epidural steroid injections safety recommendations by the Multi-Society Pain
Workgroup (MPW): More regulations without evidence or clarification. Pain Physician 2014; 17: E575-E588.

8. Work group passes epidural steroid injection consensus in response to FDA warning. www.healio.com/spine-surgery/ guidelines/news/online/\%7 $\mathrm{B}_{3} \mathrm{fb}_{7}$ ac39$d_{a f}-4305-9 d_{37-6089 d}{ }_{51 a 95} d_{7 \%} \%$ D/ work-group-passes-epidural-steroid-injection-consensus-in-response-to-fdawarning

9. Meeting Minutes from the Safety of Epidural Steroid Injections Webinar/Teleconference, January 31, 2013.

10. Landers MH, Dreyfuss P, Bogduk N. On the geometry of fluoroscopy views for cervical interlaminar epidural injections. Pain Med 2012; 13:58-65.

11. Furman $M B$, Furman $M$, Jasper $N R$, Lin HW. Fluoroscopic contralateral oblique view in interlaminar interventions: A technical note. Pain Med 2012; 13:13891396

12. Gill JS, Aner M, Jyotsna N, Keel JC, Simopoulos TT. Contralateral oblique view is superior to lateral view for interlaminar cervical and cervicothoracic epidural access. Pain Med 2015; 16:68-80.

13. Gill J, Aner M, Simopoulos T. Intricacies of the contralateral oblique view for interlaminar epidural access. Pain Med 2013; 14:1265-1266.

14. Furman MB, Jasper NR, Lin HT. In response to "Intricacies of the contralateral oblique view for interlaminar epidural access." Pain Med 2013; 14:1267-1268.

15. Jain G, Helm ER, Nedeljkovic SS, Wasan $A D$, Wang $\mathrm{H}$. Multicenter survey of attitudes and perceptions of pain medicine fellows toward the use of lateral versus contralateral-oblique fluoroscopic view for interlaminar cervical epidural injection. Pain Med 2015 Feb 26. [Epub ahead of print].

16. Abbasi A, Malhotra G. The "swimmer's view" as alternative when lateral view is inadequate during interlaminar cervical epidural steroid injections. Pain Med 2010; 11:709-712.

17. Park SY, Leem JG, Jung SH, Kim YK, Koh WU. An alternative approach to needle placement in cervicothoracic epidural injections. Korean J Pain 2012; 25:183-187.

18. Singh $H$, Meyer SA, Hecht AC, Jenkins AL 3 rd. Novel fluoroscopic technique for localization at cervicothoracic levels. J Spinal Disord Tech 2009; 22:615-618.

19. Fujinaka MK, Lawson EF, Schulteis G,
Wallace MS. Cervical epidural depth: Correlation between needle angle, cervical anatomy, and body surface area. Pain Med 2012; 13:665-669.

20. Zhu J, Falco FJ, Formoso F, Onyewu O, Irwin FL. Alternative approach for lumbar transforaminal epidural steroid injections. Pain Physician 2011; 14:331-341.

21. Goodman B, Petalcorin JS, Mallempati S. Optimizing patient positioning and fluoroscopic imaging for the performance of cervical interlaminar epidural steroid injections. PM R 2010; 2:783-786.

22. Vaisman J. Alternative view for the interlaminar cervical epidural steroid injections. Pain Med 2010; 11:1743; author reply 1744 .

23. Kim WJ, Kim TH, Shin HY, Kang H, Baek $\mathrm{CW}$, Jung YH, Woo YC, Kim JY, Koo GH, Park SG. Fluoroscope guided epidural needle insertioin in midthoracic region: Clinical evaluation of Nagaro's method. Korean J Anesthesiol 2012; 62:441-447.

24. Williams MT. The oblique interlaminar approach for fluoroscopy-guided lumbar puncture: Keep the eye opened! Diagn Interv Imaging 2014; 95:629-632.

25. Hodges SD, Castleberg RL, Miller T, Thornburg C. Cervical epidural steroid injection with intrinsic spinal cord damage: Two case reports. Spine (Phila Pa 1976) 1998; 23:2137-2142.

26. Aldrete JA, Mushin AU, Zapata JC, Ghaly R. Skin to cervical epidural space distances as read from magnetic resonance imaging films: Consideration of the "hump pad." J Clin Anesth 1998; 10:309213.

27. Hogan QH. Epidural anatomy examined by cryomicrotome section. Influence of age, vertebral level, and disease. Reg Anesth 1996; 21:395-406.

28. Goel A, Pollan JJ. Contrast flow characteristics in the cervical epidural space: An analysis of cervical epidurograms. Spine (Phila Pa 1976) 2006; 31:1576-1579.

29. Cohen SP, Gupta A, Strassels SA, Christo PJ, Erdek MA, Griffith SR, Kurihara C, Buckenmaier CC III, Cornblath D, $\mathrm{Vu}$ TN. Effect of MRI on treatment results or decision-making in patients with lumbosacral radiculopathy referred for epidural steroid injections: A multicenter, randomized controlled trial. Arch Intern Med 2012; 172:134-142.

30. Manchikanti L. Cervical epidural steroid injection with intrinsic spinal cord damage. Spine (Phila Pa 1976) 1999; 24:1170- 
1172.

31. Lirk P, Kolbitsch C, Putz G, Colvin J, Colvin $\mathrm{HP}$, Lorenz I, Keller C, Kirchmair L, Rieder J, Moriggl B. Cervical and high thoracic ligamentum flavum frequently fails to fuse in the midline. Anesthesiology 2003; 99:1387-1390.

32. Tatarek NE. Variation in the human cervical neural canal. Spine J 2005; 5:623631.

33. Eismont FJ, Clifford S, Goldberg $M$, Green B. Cervical sagittal spinal canal size in spine injury. Spine 1984; 9:663666.

34. Manchikanti L, Malla Y, Wargo BW, Cash KA, Pampati V, Fellows B. A prospective evaluation of complications of 10,000 fluoroscopically directed epidural injections. Pain Physician 2012; 15:131-140.

35. Manchikanti L, Malla Y, Cash K, Pampati V. Do the Gaps in Ligamentum Flavum in Cervical Spine translate into Dural Punctures? Analysis of Evidence and Lack of Applicability of Controversial Policies. Pain Physician 2015; Submitted for publication.

36. Shafer SL Anesthesiologists make a difference. Anesth Analg 2015; 120:497-498.

37. Maxwell BG, Hogue CW, Pronovost PJ. Does it matter who the anesthesiologist is for my heart surgery? Anesth Analg 2015; 120:499-501.

38. Wijeysundera DN, Beattie WS. Facing the uncomfortable truth: Your choice of anesthesiologist does matter. Anesth Analg 2015; 120:502-503.

39. Leslie K, Merry AF. Cardiac surgery: All for one and one for all. Anesth Analg 2015; 120:504-506.

40. Dutton RP. Making a difference: the anesthesia quality institute. Anesth Analg 2015; 120:507-509.

41. Glance LG, Kellermann AL, Hannan EL, Fleisher LA, Eaton MP, Dutton RP, Lustik SJ, Li Y, Dick AW. The impact of anesthesiologists on coronary artery bypass graft surgery outcomes. Anesth Analg 2015; 120:526-533.

42. El-Yahchouchi C, Geske JR, Carter RE, Diehn FE, Wald JT, Murthy NS, Kaufman TJ, Thielen KR, Morris JM, Amrami KK, Maus TP. The noninferiority of the nonparticulate steroid dexamethasone and triamcinolone in lumbar transforaminal epidural steroid injections. Pain Med 2013; 14:1650-1657.

43. Kennedy DJ, Plastaras C, Casey E, Visco CJ, Rittenberg JD, Conrad B, Sigler J, Dreyfuss P. Comparative effectiveness of lumbar transforaminal epidural ste- roid injections with particulate versus nonparticulate corticosteroids for lumbar radicular pain due to intervertebral disc herniation: A prospective, randomized, double-blind trial. Pain Med 2014; 15:548-555

44. Bicket M, Gupta A, Brown CH, Cohen SP. Epidural injections for spinal pain: A systematic review and meta-analysis evaluating the "control" injections in randomized controlled trials. Anesthesiology 2013; 119:907-931.

45. Manchikanti L, Nampiaparampil DE, Manchikanti KN, Falco FJE, Singh V, Benyamin RM, Kaye AD, Sehgal N, Soin A, Simopoulos TT, Bakshi S, Gharibo CG, Gilligan CJ, Hirsch JA. Comparison of the efficacy of saline, local anesthetics, and steroids in epidural and facet joint injections for the management of spinal pain: A systematic review of randomized controlled trials. Surg Neurol Int 2015; in press.

46. Manchikanti L, Cash KA, Pampati V, Malla Y. Two-year follow-up results of fluoroscopic cervical epidural injections in chronic axial or discogenic neck pain: A randomized, double-blind, controlled trial. Int J Med Sci 2014; 11:309-320.

47. Manchikanti L, Cash KA, Pampati V, Wargo BW, Malla Y. A randomized, double-blind, active control trial of fluoroscopic cervical interlaminar epidural injections in chronic pain of cervical disc herniation: Results of a 2-year follow-up. Pain Physician 2013; 16:465-478.

48. Manchikanti L, Malla Y, Cash KA, McManus $C D$, Pampati V. Fluoroscopic epidural injections in cervical spinal stenosis: Preliminary results of a randomized, double-blind, active control trial. Pain Physician 2012; 15:E59-E70.

49. Manchikanti L, Malla Y, Cash KA, McManus $C D$, Pampati V. Fluoroscopic cervical interlaminar epidural injections in managing chronic pain of cervical postsurgery syndrome: Preliminary results of a randomized, double-blind active control trial. Pain Physician 2012; 15:1326.

50. Manchikanti L, Singh V, Cash KA, Pampati V, Damron KS, Boswell MV. Effect of fluoroscopically guided caudal epidural steroid or local anesthetic injections in the treatment of lumbar disc herniation and radiculitis: A randomized, controlled, double blind trial with a two-year follow-up. Pain Physician 2012; 15:273-286.

51. Manchikanti L, Cash KA, McManus CD Pampati V. Fluoroscopic caudal epidural injections in managing chronic axial low back pain without disc herniation, radiculitis or facet joint pain. J Pain Res 2012; 5:381-390.

52. Manchikanti L, Singh V, Cash KA, Pampati V, Datta S. Fluoroscopic caudal epidural injections in managing post lumbar surgery syndrome: Two-year results of a randomized, double-blind, activecontrol trial. Int J Med Sci 2012; 9:582591.

53. Manchikanti L, Cash KA, McManus CD, Pampati V, Fellows B. Results of 2-year follow-up of a randomized, doubleblind, controlled trial of fluoroscopic caudal epidural injections in central spinal stenosis. Pain Physician 2012; 15:371384.

54. Manchikanti L, Cash KA, Pampati V, Falco FJE. Transforaminal epidural injections in chronic lumbar disc herniation: A randomized, double-blind, active-control trial. Pain Physician 2014; 17:E489-E501.

55. Manchikanti L, Cash KA, McManus CD, Pampati $V$, Benyamin RM. Thoracic interlaminar epidural injections in managing chronic thoracic pain: A randomized, double-blind, controlled trial with a 2-year follow-up. Pain Physician 2014; 17:E327-E338.

56. Manchikanti L, Singh V, Cash KA, Pampati $\vee$, Falco FJE. A randomized, doubleblind, active-control trial of the effectiveness of lumbar interlaminar epidural injections in disc herniation. Pain Physician 2014; 17:E61-E74.

57. Manchikanti L, Cash KA, McManus CD, Pampati $V$, Benyamin RM. A randomized, double-blind, active-controlled trial of fluoroscopic lumbar interlaminar epidural injections in chronic axial or discogenic low back pain: Results of a 2-year follow-up. Pain Physician 2013; 16:E491-E504.

58. Manchikanti L, Cash KA, McManus CD, Damron KS, Pampati V, Falco FJE. A randomized, double-blind controlled trial of lumbar interlaminar epidural injections in central spinal stenosis: 2-year follow-up. Pain Physician 2015; 18:79-92.

59. Park $\mathrm{CH}$, Lee $\mathrm{SH}$, Kim BI. Comparison of the effectiveness of lumbar transforaminal epidural injection with particulate and nonparticulate corticosteroids in lumbar radiating pain. Pain Med 2010; 11:1654-1658.

6o. Dreyfuss P, Baker R, Bogduk N. Comparative effectiveness of cervical transforaminal injections with particulate and nonparticulate corticosteroid prep- 
arations for cervical radicular pain. Pain Med 2006; 7:237-242.

61. McLean JP, Sigler JD, Plastaras CT, Garvan CW, Rittenberg JD. The rate of detection of intravascular injection in cervical transforaminal epidural steroid injections with and without digital subtraction angiography. PM R 2009; 1:636642.

62. Hong JH, Kim SY, Huh B, Shin HH. Analysis of inadvertent intradiscal and intravascular injection during lumbar transforaminal epidural steroid injections: A prospective study. Reg Anesth Pain Med 2013; 38:520-525.

63. Lee $M H$, Yang KS, Kim $\mathrm{YH}$, Jung $H D$, Lim SJ, Moon DE. Accuracy of live fluoroscopy to detect intravascular injection during lumbar transforaminal epidural injections. Korean J Pain 2010; 23:18-23.

64. Maus T, Schueler BA, Leng S, Magnuson D, Magnuson DJ, Diehn FE. Radiation dose incurred in the exclusion of vascular filling in transforaminal epidural steroid injections: Fluoroscopy, digital subtraction angiography, and CT/fluoroscopy. Pain Med 2014; 15:1328-1333.

65. Chang Chien GC, Candido KD, Knezevic NN. Digital subtraction angiography does not reliably prevent paraplegia associated with lumbar transforaminal epidural steroid injection. Pain Physician 2012; 15:515-523.

66. Visnjevac O, Kim P, Farid-Davari S, Johnson P, Nader ND. Digital subtraction angiography versus real-time fluoroscopy for detection of intravascular penetration prior to epidural steroid injections: Meta-analysis of prospective studies. Pain Physician 2015; 18:29-36.

67. Candido KD. Critical Items to consider before adopting advocacy of digital subtraction angiography. Pain Physician 2015; 18:37-38.

68. Bogduk N. Lumbar interlaminar epidural access. In: Practice Guidelines for Spinal Diagnostic and Treatment Procedures. 2nd edition. International Spine Intervention Society (ISIS), San Francisco, 2013, pp 539-558.

69. Bogduk N. Thoracic transforaminal access. In: Practice Guidelines for Spinal Diagnostic and Treatment Procedures. 2nd edition. International Spine Intervention Society (ISIS), San Francisco, 2013, pp 329-350.

70. Atluri S, Glaser SE, Shah RV, Sudarshan $\mathrm{G}$ : Needle position analysis in cases of paralysis from transforaminal epidurals: Consider alternative approaches to traditional technique. Pain Physician 2013
16:321-334.

71. Murthy NS, Maus TP, Behrns CL. Intraforaminal location of the great radiculomedullary artery (artery of Adamkiewicz): A retrospective review. Pain Med 2010; 11:1756-1764.

72. Windsor RE, Storm S, Sugar R, Nagula D. Cervical transforaminal injection: Review of the literature, complications, and a suggested technique. Pain Physician 2003; 6:457-465.

73. Engel A, King W, MacVicar J; Standards Division of the International Spine Intervention Society. The effectiveness and risks of fluoroscopically guided cervical transforaminal injections of steroids: A systematic review with comprehensive analysis of the published data. Pain Med 2014; 15:386-402.

74. Shah RV. Paraplegia following thoracic and lumbar transforaminal epidural steroid injections: How relevant are particulate steroids? Pain Pract 2014; 14:297300.

75. Shah RV. Paraplegia following thoracic and lumbar transforaminal epidural steroid injections: How relevant is physician negligence? ] Neurointerv Surg 2014; 6:166-168.

76. Gharibo C, Koo C, Chung J, Moroz A. Epidural steroid injections: An update on mechanisms of injury and safety. Reg Anes Pain Manag 2009; 13:266-271.

77. Huntoon MA. Anatomy of the cervical intervertebral foramina: Vulnerable arteries and ischemic neurologic injuries after transforaminal epidural injections. Pain 2005; 117:104-111.

78. Kim do W, Han KR, Kim C, Chae YJ. Intravascular flow patterns in transforaminal epidural injections: A comparative study of the cervical and lumbar vertebral segments. Anesth Analg 2009; 109:233-239.

79. Rathmell JP. Toward improving the safety of transforaminal injection. Anesth Analg 2009; 109:8-10.

8o. Tiso RL, Cutler T, Catania JA, Whalen K. Adverse central nervous system sequelae after selective transforaminal block: The role of corticosteroids. Spine ] 2004; 4:468-474.

81. Rathmell JP, Aprill C, Bogduk N. Cervical transforaminal injection of steroids. Anesthesiology 2004; 100:1595-1600.

82. Scanlon GC, Moeller-Bertram T, Romanowsky SM, Wallace MS. Cervical transforaminal epidural steroid injections: More dangerous than we think? Spine (Phila Pa 1976) 2007; 32:1249-1256.
83. Park KD, Lee J, Jee H, Park Y. Kambin triangle versus the supraneural approach for the treatment of lumbar radicular pain. Am J Phys Med Rehabil 2012; 91:1039-1050.

84. Manchikanti L, Abdi S, Atluri S, Benyamin RM, Boswell MV, Buenaventura RM, Bryce DA, Burks PA, Caraway DL, Calodney AK, Cash KA, Christo PJ, Cohen SP, Colson J, Conn A, Cordner HJ, Coubarous S, Datta S, Deer TR, Diwan SA, Falco FJE, Fellows B, Geffert SC, Grider JS, Gupta S, Hameed H, Hameed M, Hansen H, Helm II S, Janata JW, Justiz R, Kaye AD, Lee M, Manchikanti KN, McManus CD, Onyewu O, Parr AT, Patel VB, Racz GB, Sehgal N, Sharma $M$, Simopoulos TT, Singh V, Smith HS, Snook LT, Swicegood J, Vallejo R, Ward SP, Wargo BW, Zhu J, Hirsch JA. An update of comprehensive evidence-based guidelines for interventional techniques of chronic spinal pain: Part II: Guidance and recommendations. Pain Physician 2013; 16:S49-S283.

85. Bogduk N, Brazenor G, Christophidis N, Cherry D, Fraser R, Jenkins J, Little TF, Ditton J, Jeffries R. Epidural use of steroids in the management of back pain. Report of working party on epidural use of steroids in the management of back pain. National Health and Medical Research Council. Commonwealth of Australia, Canberra, 1994, pp 1-76.

86. Pettit AC, Malani AN. Outbreak of fungal infections associated with contaminated methylprednisolone acetate: An update. Curr Infect Dis Rep 2015; 17:441.

87. Manchikanti L, Pampati V, Falco FJE, Hirsch FJE. An updated assessment of utilization of interventional pain management techniques in the Medicare population: $2000-2013$. Pain Physician 2015;18:115-E127.

88. Manchikanti L, Helm II S, Singh V, Hirsch JA. Accountable interventional pain management: A collaboration among practitioners, patients, payers, and government. Pain Physician 2013; 16:E635-E670.

89. Benzon HT, Chew TL, McCarthy RJ, Benzon HA, Walega DR. Comparison of the particle sizes of different steroids and the effect of dilution: A review of the relative neurotoxicities of the steroids. Anesthesiology 2007; 106:331-338.

90. Derby R, Lee SH, Date ES, Lee JH, Lee $\mathrm{CH}$. Size and aggregation of corticosteroids used for epidural injections. Pain Med 2008; 9:227-234. 
91. Dawley JD, Moeller-Bertram T, Wallace MS, Patel PM. Intraarterial injection in the rat brain: Evaluation of steroids used for transforaminal epidurals. Spine (Phila $\mathrm{Pa}$ 1976) 2009; 34:1638-1643.

92. Rozin L, Rozin R, Koehler SA, Shakir A, Ladham S, Barmada M, Dominick J, Wecht $\mathrm{CH}$. Death during transforaminal epidural steroid nerve root block $\left(\mathrm{C}_{7}\right)$ due to perforation of the left vertebral artery. Am J Forensic Med Pathol 2003; 24:351-355.

93. Wallace MA, Fukui MB, Williams RL, Ku A, Baghai P. Complications of cervical selective nerve root blocks performed with fluoroscopic guidance. Am J Roentgenol 2007; 188:1218-1221.

94. Glaser SE, Falco F. Paraplegia following a thoracolumbar transforaminal epidural steroid injection. Pain Physician 2005; 8:309-314.

95. Glaser SE, Shah RV. Root cause analysis of paraplegia following transforaminal epidural steroid injections: The 'unsafe' triangle. Pain Physician 2010; 13:237-244.

96. Manchikanti L, Hirsch JA. Neurologic complications associated with epidural steroid injections. Curr Pain Headache Rep 2015;19:482.

97. Manchikanti L, Benyamin RM, Falco FJ, Kaye AD, Hirsch JA. Do epidural injections provide short- and long-term relief for lumbar disc herniation? A systematic review. Clin Orthop Relat Res 2014 Feb 11. [Epub ahead of print].

98. Manchikanti L, Nampiaparampil DE, Candido KD, Bakshi S, Grider JS, Falco FJE, Sehgal N, Hirsch JA. Do cervical epidural injections provide long-term relief in neck and upper extremity pain? A systematic review. Pain Physician 2015; 18:39-60.

99. Manchikanti L, Falco FJ, Diwan S, Hirsch JA, Smith HS. Cervical radicular pain:
The role of interlaminar and transforaminal epidural injections. Curr Pain Headache Rep 2014; 18:389.

100. Candido KD, Knezevic N. Cervical epidural steroid injections for the treatment of cervical spinal (neck) pain. Curr Pain Headache Rep 2013; 17:314.

101. Datta S, Everett CR, Trescot AM, Schultz DM, Adlaka R, Abdi S, Atluri SL, Smith HS, Shah RV. An updated systematic review of diagnostic utility of selective nerve root blocks. Pain Physician 2007; 10:113-128.

102. Datta S, Manchikanti L, Falco FJE, Calodney AK, Atluri S, Benyamin RM, Buenaventura R, Cohen SP. Diagnostic utility of selective nerve root blocks in the diagnosis of lumbosacral radicular pain: Systematic review and update of current evidence. Pain Physician 2013; 16:SE97-SE124.

103. Shah RV. The problem with diagnostic selective nerve root blocks. Spine (Phila Pa 1976) 2012; 37:1991-1993.

104. Hodler J, Boos N, Schubert M. Must we discontinue selective cervical nerve root blocks? Report of two cases and review of the literature. Eur Spine J 2013; 22:S466-S470.

105. Slipman CW, Plastaras CT, Palmitier RA, Huston CW, Sterenfeld EB. Symptom provocation of fluoroscopically guided cervical nerve root stimulation. Are dynatomal maps identical to dermatomal maps? Spine (Phila Pa 1976) 1998; 23:2235-2242.

106. Chung JY, Yim JH, Seo HY, Kim SK, Cho $\mathrm{KJ}$. The efficacy and persistence of selective nerve root block under fluoroscopic guidance for cervical radiculopathy. Asian Spine J 2012; 6:227-232.

107. Wolter T, Knoeller S, Berlis A, Hader C. $C T$-guided cervical selective nerve root block with a dorsal approach. AJNR Am J
Neuroradiol 2010; 31:1831-1836.

108. Eubanks JD. Cervical radiculopathy: Nonoperative management of neck pain and radicular symptoms. Am Fam Physician 2010; 81:33-40.

109. Eckel TS, Bartynski WS. Epidural steroid injections and selective nerve root blocks. Tech Vasc Interv Radiol 2009; 12:11-21.

110. Wolter T, Mohadjer M, Berlis A, Knoeller S. Cervical CT-guided, selective nerve root blocks: improved safety by dorsal approach. AJNR Am J Neuroradiol 2009; 30:336-337.

111. Kumar N, Gowda V. Cervical foraminal selective nerve root block: A "two-needle technique" with results. Eur Spine J 2008; 17:576-584.

112. Anderberg L, Annertz M, Persson L, Brandt L, Säveland $H$. Transforaminal steroid injections for the treatment of cervical radiculopathy: A prospective and randomised study. Eur Spine ] 2007; 16:321-328.

113. Anderberg L, Säveland $H$, Annertz $M$. Distribution patterns of transforaminal injections in the cervical spine evaluated by multi-slice computed tomography. Eur Spine J 2006; 15:1465-1471.

114. Anderberg L, Annertz M, Rydholm U, Brandt L, Säveland $H$. Selective diagnostic nerve root block for the evaluation of radicular pain in the multilevel degenerated cervical spine. Eur Spine J 2006; 15:794-801.

115. Strobel K, Pfirrmann CW, Schmid M, Hodler J, Boos N, Zanetti M. Cervical nerve root blocks: Indications and role of MR imaging. Radiology 2004; 233:8792.

116. Wagner AL, Murtagh FR. Selective nerve root blocks. Tech Vasc Interv Radiol 2002; 5:194-200. 